\title{
18. GEOCHEMICAL AND OPTICAL INVESTIGATIONS ON DEGRADATION PROCESSES AFFECTING ORGANIC MATTER IN CELEBES BASIN SEDIMENTS1
}

\author{
E. Lallier-Vergès, ${ }^{2}$ P. Bertrand, ${ }^{2}$ A. Desprairies,${ }^{3}$ and U. Berner ${ }^{4}$
}

\begin{abstract}
Celebes Basin sediments from Ocean Drilling Program Site 767 (Leg 124) containing both marine and terrestrial organic matter have been investigated through palynofacies and geochemical analyses. The main degradation processes affecting or having affected organic matter are recorded in the sedimentary column as shown by ammonium, phosphate and sulfate pore-water profiles, and by petrographic and geochemical analyses of sediments.

In the upper part of the sedimentary section (down to $200 \mathrm{mbsf}$ ), the decrease of the ratio of total organic carbon to sulfur (TOC/S) with depth, generally related to the sulfate reduction process, is accompanied by an increase of framboidal pyrite content in the marine organic matter, and by an increasing amount of amorphous marine organic matter relative to the total organic matter. However, as the terrestrial organic input also varies with depth, dilution effects are superimposed on diagenesis. This continental supply affects the TOC/S ratio by increasing total organic carbon and decreasing the ability of the bulk organic matter to be metabolized through sulfate reduction. A positive relationship between the TOC/P ratio and the amount of degraded organic matter of marine origin clearly displays the effect of an organic source on the composition of the sediment. Each lithostratigraphic unit possesses its own characteristics in terms of composition and preservation of organic matter. The effects of diagenesis can only be appreciated within a single lithostratigraphic unit and mainly affect the less-resistant marine organic matter.
\end{abstract}

\section{INTRODUCTION}

It is now well known that the main processes influencing the degradation of organic matter in surficial sediments $\left(\mathrm{O}_{2}\right.$ consumption, fermentation, denitrification, sulfate reduction, and methanogenesis) are related to the rate of sediment accumulation and the inferred availability of reactive organic matter (Sorokin, 1962; Toth and Lerman, 1977; Westrich and Berner, 1984; Henrichs and Reeburgh, 1987). These diagenetic processes are mediated by specific micro-organisms. Among them, sulfate-reducing bacteria make a large contribution to the mineralization of organic matter (Jorgensen, 1982).

The record of diagenetic processes in pore waters deeper than the first meters indicates that this type of diagenesis may still be active at greater depths (Manheim and Sayles, 1974). The effects of this diagenesis on the fossilized organic matter are difficult to assess and are poorly documented by petrographical studies.

The occurrence of numerous detrital turbidite levels in the Celebes Basin sediments masks the diagenetic evolution of the autochthonous organic matter. The aim of this paper is to investigate possible effects of these late processes on the character of the organic matter, as reflected by the optical and isotopic study of kerogen, and in the amount of organic carbon, total nitrogen, total phosphorus, and total sulfur in the sediment. Our work consisted mainly of microscopic studies of isolated organic matter and pyrite, compared to geochemical results obtained from sediments. The pore-water analyses that were previously published in Rangin, Silver, von Brey-

\footnotetext{
${ }^{1}$ Silver, E. A., Rangin, C., von Breymann, M. T., et al., 1991. Proc. ODP, Sci. Results, 124: College Station, TX (Ocean Drilling Program).

${ }^{2}$ URA 724 du CNRS, Unité de Recherche en Pétrologie Organique, Université d'Orléans, 45067 Orléans, France.

${ }^{3}$ URA 723 du CNRS, Laboratoire de Géochemie des Roches Sédimentaires, Université Paris Sud, Bât. 504, 91405 Orsay, France.

${ }^{4}$ Bundesanstalt für Geowissenschaften und Rohstoffe, Stilleweg 2, 3000 Hannover 51, Federal Republic of Germany.
}

mann, et al., (1990), are presented to show that the studied processes are still active.

We have focused the comparison between petrographic and geochemical data on the upper part of the sedimentary column ( 0 to $200 \mathrm{mbsf}$ ), to define the conditions of preservation and/or degradation of the marine organic matter in the most recent sediments.

\section{ANALYTICAL TECHNIQUES}

The nonhydrolyzable organic matter was isolated using successive chemical treatments ( $\mathrm{HF}, \mathrm{HCI}, \mathrm{KOH}$, and finally $\mathrm{HNO}_{3}$ ), to leach the mineral fractions. The sample was observed microscopically at two stages of preparation: before (organic matter and pyrite) and after oxidizing (only organic matter) treatment, according to the method for palynofacies studies used for Leg 117 (Bertrand et al., 1991). This classical method allows one to isolate most of the sedimentary organic matter components.

A mechanical separation (by sieving) was attempted, to observe the effects of chemical attacks on some organic components. In contrast with palynofacies preparation, wet-sieving did not remove humic substances. Coarse fractions $(>125 \mu \mathrm{m}$, 80-125 $\mu \mathrm{m}, 40-80 \mu \mathrm{m}, 20-40 \mu \mathrm{m}$, and $<20 \mu \mathrm{m}$ ) were sieved under double-distilled water and prepared for scanning electron microscopy (SEM) observations. The organic components were studied by means of optical and electron microscopes.

Total chemical analyses were carried out on homogenized powders using a quantitative energy dispersive spectrometer (EDS) coupled to a SEM. Total sulfur and total organic carbon was measured using a combustion system (LECO equipment). Organic sulfur was analyzed in four samples after a selective extraction with carbon sulfide (Table 1).

The type of organic matter was evaluated by means of the Delsi Rock Eval pyrolysis apparatus as described by Espitaliè et al., (1977). Only the results obtained on sediments having TOC $>0.3 \%$, were taken into account because of artifacts due to possible retention of hydrocarbons on clays when TOC is low. The method for carbon isotope composition analysis of kerogens is that of Schoell (1984), and the data are presented in Table 2. 
Table 1. Position of samples in lithostratigraphic and Organic Facies Units as defined in Rangin, Silver, von Breymann et al. (1990).

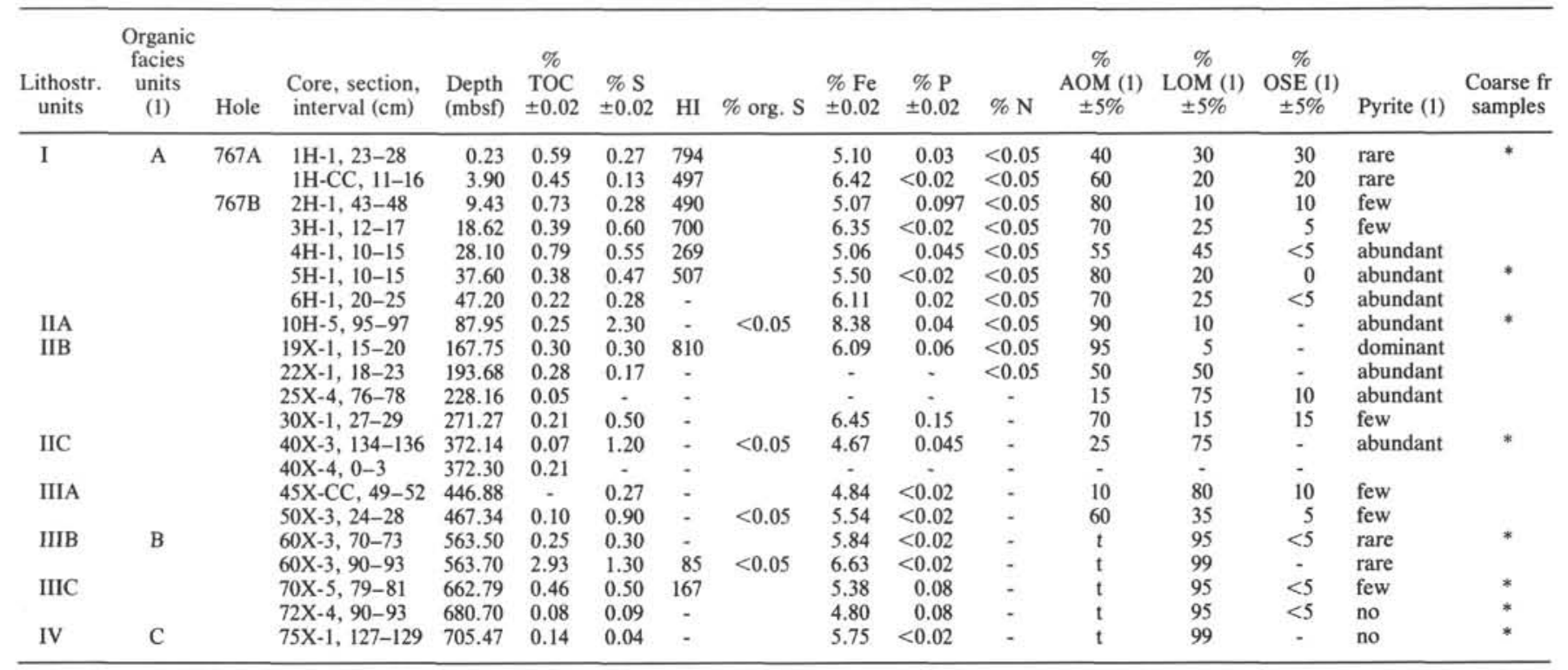

Depth in the hole (mbsf); \% total organic carbon (TOC) and \% total sulfur (S) (measured by a combustion LECO system; \% organic sulfur (see in text); HI (mg/g TOC) Hydrogen Index from Rock Eval Pyrolysis, \% total phosphorus (P) and \% total iron (Fe) measured by EDS; \% nitrogen data (C, H, N system). (1) Qualitative data concerning organic components estimated in isolated organic matter are from Bertrand et al, this volume. AOM $=$ amorphous organic matter; $\mathrm{OSE}=$ other structured elements; LOM = lignaceous organic matter. Pyrite amount is estimated on the slide set up before oxidizing.

Table 2. Distribution of isotopic carbon composition data of kerogen with depth in the hole.

\begin{tabular}{lcccc}
\hline $\begin{array}{c}\text { Lithostr. } \\
\text { units }\end{array}$ & $\begin{array}{c}\text { Organic facies } \\
\text { units (1) }\end{array}$ & $\begin{array}{c}\text { Core, section, } \\
\text { interval (cm) }\end{array}$ & $\begin{array}{c}\text { Depth } \\
\text { (mbsf) }\end{array}$ & $\delta^{13} \mathrm{C} \%$ \\
\hline I & A & 1H-5, 0-3 & 6.00 & -22.00 \\
IIA & & $7 \mathrm{H}-5,0-3$ & 62.5 & -21.84 \\
& & $8 \mathrm{H}-4,0-3$ & 70.5 & -22.29 \\
IIB & & $21 \mathrm{X}-5,0-3$ & 189.8 & -21.60 \\
IIC & & $30 \mathrm{X}-5,0-3$ & 364.1 & -23.43 \\
IIIA & & $46 \mathrm{X}-5,0-3$ & 431.8 & -24.15 \\
& & $49 \mathrm{X}-2,0-3$ & 456.3 & -26.08 \\
IIIB & \multirow{2}{*}{ B } & $51 \mathrm{X}-3,0-3$ & 477.8 & -26.08 \\
& & $53 \mathrm{X}-5,0-3$ & 499.0 & -25.93 \\
& & $54 \mathrm{X}-3,0-3$ & 505.5 & -27.33 \\
& & $55 \mathrm{X}-4,0-3$ & 516.7 & -23.03 \\
& & $56 \mathrm{X}-4,0-3$ & 525.6 & -25.08 \\
& & $57 \mathrm{X}-4,0-3$ & 535.3 & -25.88 \\
& & $59 \mathrm{X}-4,0-3$ & 554.7 & -25.47 \\
\hline
\end{tabular}

(1) Organic facies Units are defined in Bertrand et al., this volume.

Analyses of interstitial waters were carried out on board. Results are reported in Rangin, Silver, von Breymann et al., 1990.

\section{GENERAL RESULTS FROM SITE 767}

The sediments in the Celebes Basin are composed of three major organic sequences according to the tectonic history of the basin as defined by Bertrand et al. (this volume). The upper part (lithostratigraphic Units I, II, and IIIA) consists of mostly marine components and is called "organic facies Unit A," whereas the second part (lithostratigraphic Units IIIB, IIIC) is only composed of terrestrial constituents and called "organic facies Unit B." The deeper section (lithostratigraphic Unit IV) is mainly composed of highly degraded terrestrial material ("organic facies Unit C"). This result is based on the organic petrography of the palynofacies (see Bertrand et al., this volume) and other parameters such as clay mineralogy (Rangin, Silver, von Breymann et al., 1990).

\section{Palynofacies Results}

The organic matter of the "organic facies Unit A" is of minor to dominant autochthonous marine origin, variably diluted by strong to dominant terrestrial input from turbidites. The pyritization is moderate to strong. Pyrite occurs as framboids that are mainly associated with the amorphous marine organic matter.

The organic matter of Unit B (lithostratigraphic Units IIIB and IIIC) is dominated by a terrestrial input associated with turbidites. The marine organic component is negligible and consists of rare benthic and planktonic remains with sparse amorphous organic matter. The occurrence of pyritized plant debris in this unit, suggests that metabolizable organic matter was present within lignaceous fragments in turbidites at the time of deposition. In this unit, the optical aspect of the amorphous organic matter (finely divided gray material different from typical brown massive aggregates of marine organic matter) and its close association with lignaceous debris (Bertrand et al., this volume) further suggest that part of the terrestrial input was metabolized. Organic facies Unit C shows weak or no pyritization. This absence of pyrite may be related to the very low sedimentation rate that did not allow the fossilization of metabolizable marine organic matter to occur.

\section{$\delta^{13} \mathrm{C}$ Composition}

The carbon isotopic composition of kerogens are reported in Table 2.

$\delta^{13} \mathrm{C} \%$ is higher in the upper part of the Hole (from 0 to about $200 \mathrm{~m}$ ) indicating the dominance of the marine organic matter (Fig. 1). The turbidite layers with high TOC contents present the lowest values (to $-27.33 \%$ ), which agrees with the abundance of terrestrial organic components. In the lower part (organic facies Unit $\mathrm{B}$ ), $\delta^{13} \mathrm{C}$ is also lower because of the terrigenous nature of the organic matter, as was first postulated by Galimov (1980). 


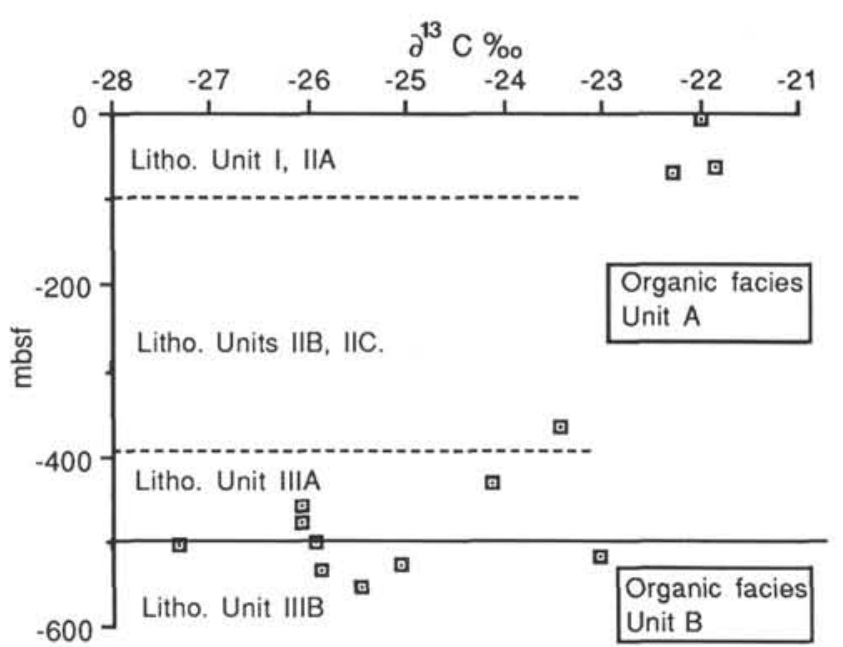

Figure 1. Distribution of $\delta^{13} \mathrm{C}$ no. composition of kerogen with depth in Hole 767. The more negative values occur down the lithostratigraphic Units IIIA and IIIB, indicating the more marked influence of terrestrial organic material in these Units.

\section{Observation of Granulometric Fractions from the Bulk Sediment}

Eight samples were studied along the sedimentary column (Table 1): four from Unit A, and three from Units B and C. These three samples were taken at the boundary with oxidized deposits. Due to the silty nature of the sediment, the $>20 \mu \mathrm{m}$ coarse fractions are well represented in all samples. In the upper part of the series, they consist mainly of volcanic glass and radiolarian tests $(80-125 \mu \mathrm{m})$ often filled with clays; lignaceous debris is also visible. Radiolarian tests as observed by binocular microscope are included in a yellow-brown material that appears as a coating on SEM views (Pl. 1.1). Zooplanktonic pellets are abundant in Unit I (Pl. 1.2).

With increasing depth, the surfaces of the volcanic glass become altered and the radiolarian tests disappear, while granular silica appears. Pyritic framboids are not observed, as they are included in the fraction $<20 \mu \mathrm{m}$. However, some framboids were described from cemented clayey aggregates from Unit IIC (PI. 2.2).

SEM studies reveal the organic nature of part of the $<20$ $\mu \mathrm{m}$ fraction (Pl. 1.3). This finely divided organic matter is associated with silicates (occurrence of $\mathrm{Si}, \mathrm{Al}, \mathrm{K}$ ). It is probable that humic substances may constitute a major part of this fraction, given their affinity to form complexes with clays.

\section{PETROGRAPHIC ORGANIC COMPONENTS IN UNIT A}

Only the depth interval where marine organic matter was found has been considered for detailed petrographic investigations; i.e., organic facies Unit A (down to about $500 \mathrm{mbsf}$ ). The results are reported in Table 1. The organic components that can be distinguished are: (1) marine organic matter, represented by both structured components, termed here other structured elements (OSE), and amorphous organic matter (AOM), and (2) continental organic matter that is mainly represented by lignaceous organic matter (LOM) and also includes a few pollen, spores, and cuticles.

\section{Marine Organic Matter}

Marine organic matter appears in the form of typical aggregates of amorphous organic matter and of structured elements. Photomicrographs of such components are also presented in Bertrand et al., this volume. The "amorphous organic matter" (AOM) is a brown-orange material (in transmitted light) that does not show a defined morphology; it represents the rests of easily metabolizable organic matter. Raynaud et al. (1988) have shown that some amorphous aggregates may have a fine structure (membrane accumulation) when examined by electron transmission microscopy. These authors proposed that this amorphous organic matter is the result of the degradation of phytoplankton. In this study we describe the AOM using transmitted light microscopy. SEM views reveal its granulous aspect (Pl. 1.4) with some framboidal pyrite included in it (Pl. 2.1).

The structured marine organic matter is composed of the most resistant components of marine organic matter (parts of algae, Pl. 2.1; dinoflagellates, Pl. 1.5, but also chitinous foraminifers, scolecodontes).

\section{Continental Organic Matter}

The terrestrial debris is mainly composed of a few pollen and spores (Pl. 1.5), rares cuticles (PI. 1.6) and abundant lignaceous debris (Pl. 2.3). These well-defined vegetal structures consist of material that is very resistant to alteration as lignin-derived compounds. The lack of pyrite in these structures, compared to the associated marine organic matter, is due to the probability that the degradation of metabolizable components has occurred during transport and before sedimentation. In contrast, the turbidites in the deeper sequences have fossilized continental debris with more metabolizable organic matter.

\section{Pyrite}

Rare amounts of pyrite have been observed in the upper part (0 to $20 \mathrm{mbsf}$ ) of the sedimentary column (Table 1), always in the form of framboids associated with the amorphous organic matter (Pl. 2.1). Its proportion in the isolated organic matter increases with depth, as does the amount of AOM. At about 167 mbsf (Sample 124A-787A-10H-5, 95-97 $\mathrm{cm}$ ), pyrite framboids are a dominant component in samples prior to the oxidizing procedure. SEM observations showed different types of framboids (SEM Pl. 2.4 and 2.6) with various crystal sizes (from 0.5 to $2 \mu \mathrm{m}$ ). Some individual framboids consist of several sizes of pyrite crystals (PI. 2.5), which could represent different steps in the crystallization process. According to the crystal types of Mn oxides at the watersediment interface in deep oxic sediments (Chuhkrov et al, 1982), the smaller crystals could be poorly-organized pyrite due to biomineralization, after which the diagenetic processes of dissolution and recrystallization leads to more perfect dodecahedral shapes.

\section{GEOCHEMICAL RESULTS}

\section{Pore Waters}

The $\mathrm{NH}_{4}^{+}$concentration in pore waters (Fig. 2, after Rangin, Silver, von Breymann et al., 1990) increases toward deeper sediments (to $150 \mathrm{mbsf}$ ), indicating the degradation of proteins and aminoacids in the absence of oxygen. This shows that degradation of nitrogen-bearing compounds may be occurring at least to this depth.

The phosphate content rapidly decreases in the pore waters from 23 to about $5 \mu \mathrm{M}$ (Fig. 3, after Rangin, Silver, von Breymann et al., 1990), suggesting the formation of phosphorus compounds in the sediment. A sharp decrease occurs between 20 and 80 mbsf. The $\mathrm{PO}_{4}^{3-}$ increase observed by many authors in the first 1 or $2 \mathrm{~m}$ of the sedimentary column and attributed to degradation of P-compounds 


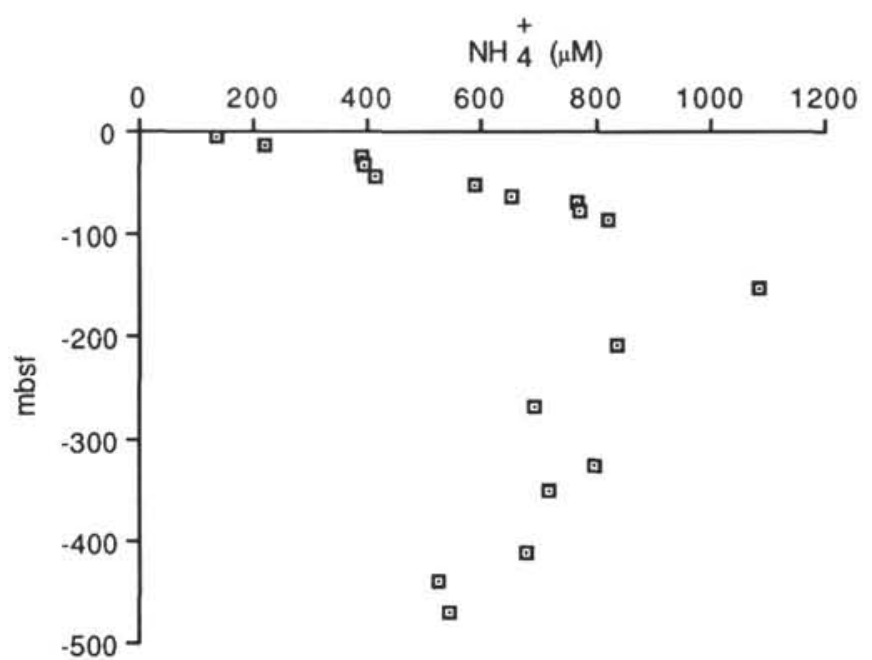

Figure 2. $\mathrm{NH}_{4}^{+}(\mu \mathrm{M})$ depth profile in pore waters, from Rangin, Silver, Von Breymann, et al., 1990.

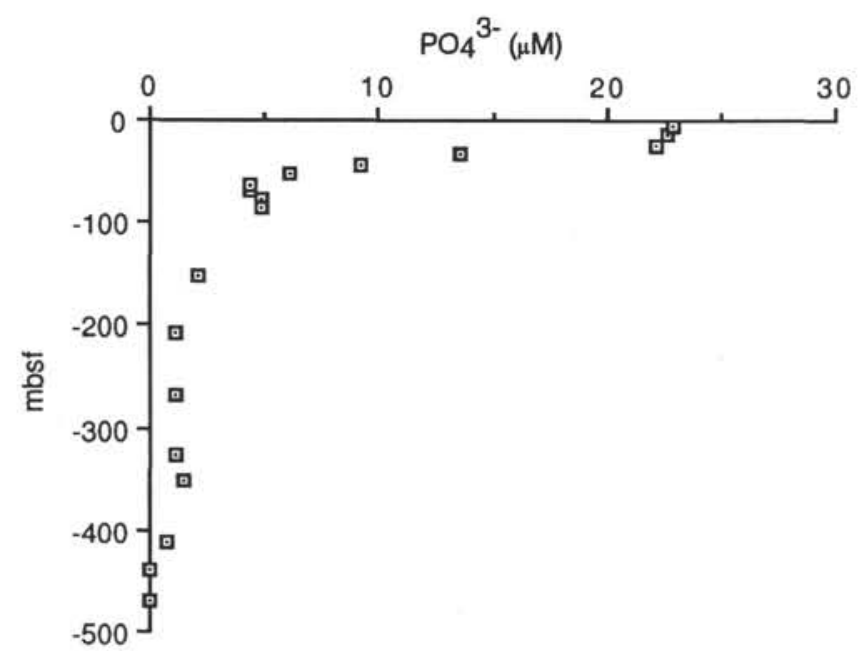

Figure 3. $\mathrm{PO}_{4}^{3-}(\mu \mathrm{M})$ depth profile in pore waters, from Rangin, Silver, von Breymann, et al., 1990.

(Berner, 1974) is not visible, probably due to poor resolution of the sampling.

In spite of the thick sequence of sediments and the inferred compositional variations of organic matter, the pore-water profile of sulfate shows a simple decrease with depth (Fig. 4). This distribution results from the bacterial degradation of organic matter. The influence of sulfate reduction in burial processes is partly related to the sediment accumulation rate. For the range of sedimentation rates observed $(4-8 \mathrm{~cm} / \mathrm{k} . \mathrm{y}$.$) ,$ Sayles and Manheim (1975) and Toth and Lerman (1977) assumed that the early preservation of metabolizable organic matter is relatively good and that sulfate reduction may continue in deep sediments. Rangin, Silver, von Breymann, et al. (1990) proposed that $\mathrm{SO}_{4}^{2-}$ consumption could also be driven by methane oxidation.

The profiles of ammonium, phosphate, and sulfate in the pore waters of the Celebes Basin sediments seem to record, until great depths, the effects of the main diagenetic processes affecting organic matter through bacterial activity. This result marks the probably weak continuation of the degradation of organic matter with increasing depth.

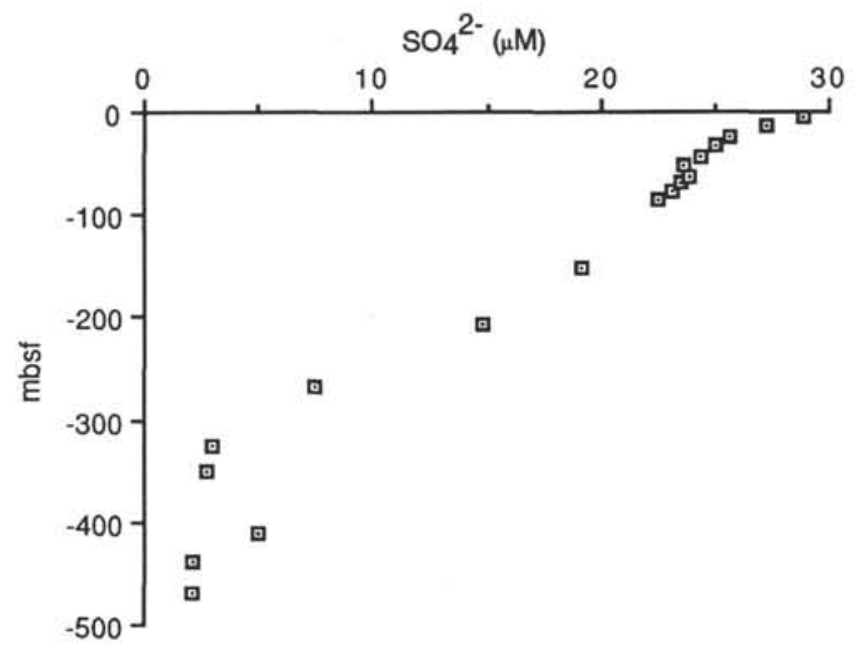

Figure 4. $\mathrm{SO}_{4}^{2-}(\mathrm{mM})$ depth profile in pore waters, from Rangin, Silver, von Breymann, et al., 1990.

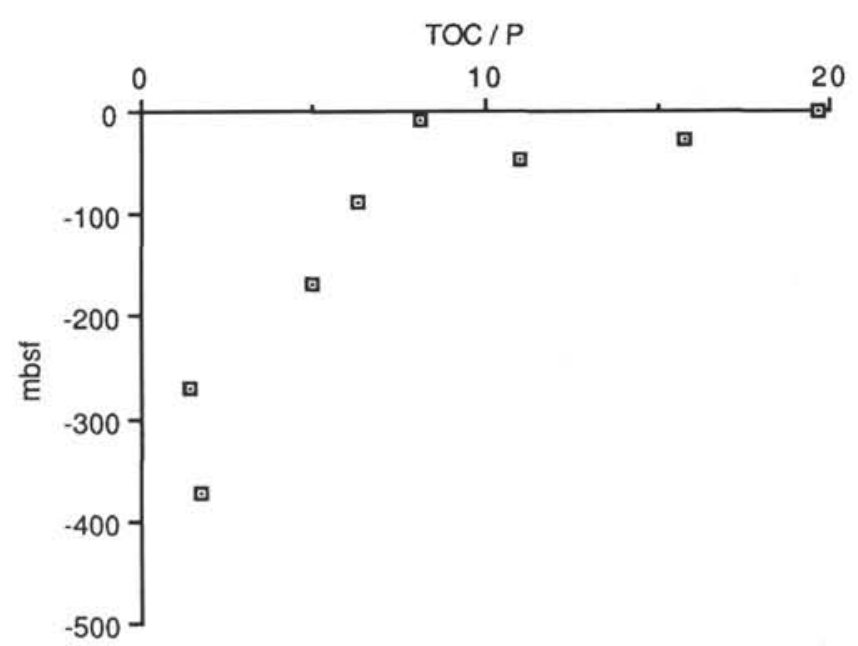

Figure 5. TOC/P weight ratio in sediment vs. depth, in the organic facies Unit A.

\section{Sediments}

From 0 to $200 \mathrm{mbsf}$, the nitrogen content of the sediments is $<0.05 \%$ (Table 1). This is in agreement with the results of Waples and Sloan (1980), which demonstrate the minimal participation of nitrogen in both mineral and organic phases. The low content of $\beta$-alanine and $\gamma$-aminobutyric acid associated with clays (Degens, 1985; Schroeder, 1975) cannot be determined with this type of analysis.

The TOC/P weight ratio of the sediment is very low $(<20)$, but it is slightly higher in the upper part of the hole (Fig. 5).

The TOC/S ratio may be considered as an approximate indicator of the sulfate reduction effect (Berner and Raiswell, 1983, 1984; Davis et al., 1988). It decreases with depth (Fig. 6), indicating that the buried sediments are subjected to a generally stronger sulfate-reducing effect than surficial sediments. This interpretation is supported by SEM studies that indicate a parallel increase in pyrite in isolated organic matter. Stronger variations of TOC/S occur in the upper unit. Organic sulfur of studied sediments is always $<0.05 \%$ (Table 1). This result and the occurrence of a high content of iron vs sulfur 
TOC/S

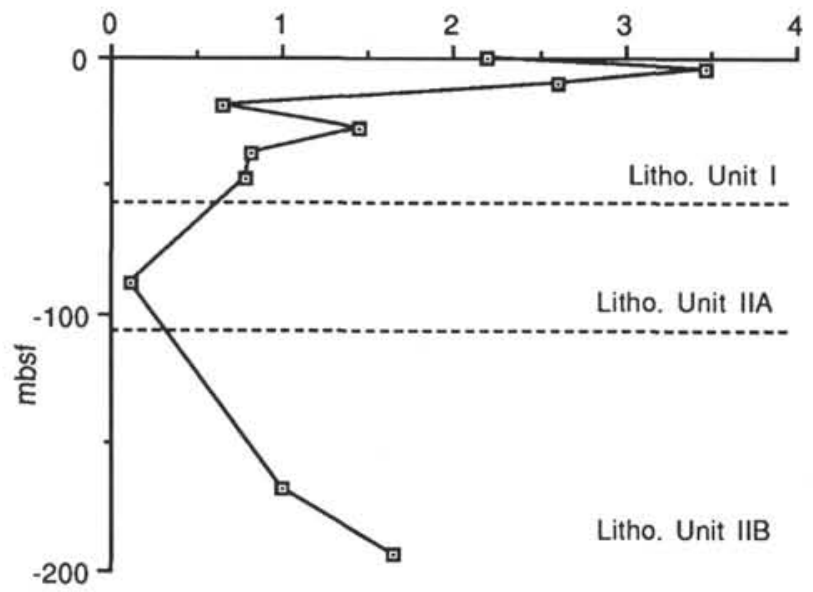

Figure 6. TOC/S weight ratio in sediment vs. depth, in the organic facies Unit A.

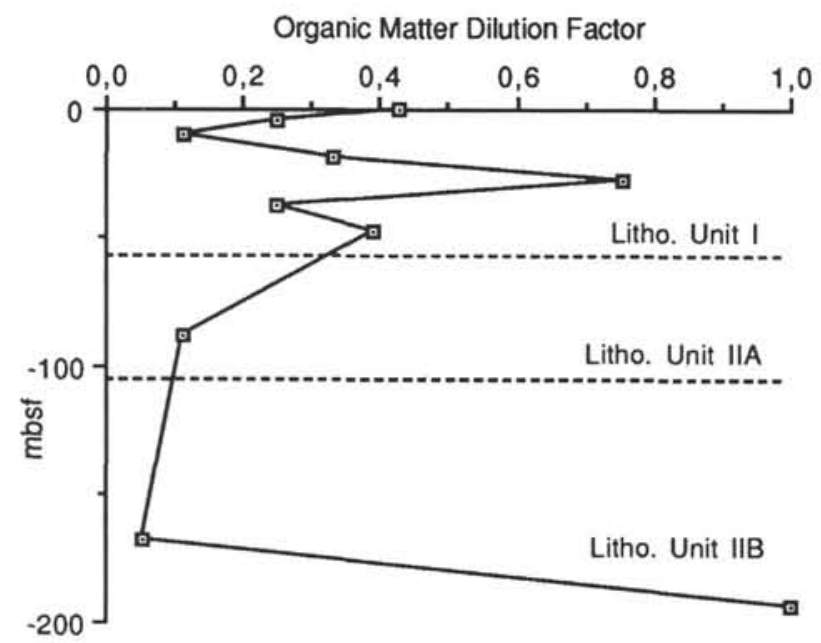

Figure 7. Distribution with depth in the hole, of the organic matter dilution factor (terrestrial/ marine organic matter). The ratio, defined as lignaceous organic matter (LOM) vs. amorphous organic matter $(\mathrm{AOM})+$ other structured elements (OSE), has been calculated using qualitative data obtained on isolated organic matter preparations.

reveals that pyritization has been the major process of mineralization compared to incorporation of sulfur in organic matter.

\section{DISCUSSION OF THE SULFATE REDUCTION EFFECTS}

We coupled the microscopic investigations of organic matter to the geochemical bulk analysis of the dominantly marine sediments (down to $200 \mathrm{mbsf}$ ), because it is unrealistic to differentiate depositional-vs.-diagenetic changes on the exclusive basis of element ratios.

We defined an "Organic Matter Dilution Factor" as the continental vs. marine component ratio. Except for the first 25 mbsf, this factor varies with depth in the same way as the sediment $\mathrm{TOC} / \mathrm{S}$ ratio; i.e., low terrestrial dilution coincides with a low TOC/S ratio (Fig. 6 and 7). This may represent the effect of the availability of metabolizable components (i.e., marine organic matter) on sulfate reduction efficiency. The occurrence of highly reactive components is revealed through the relationship between the composition of organic matter

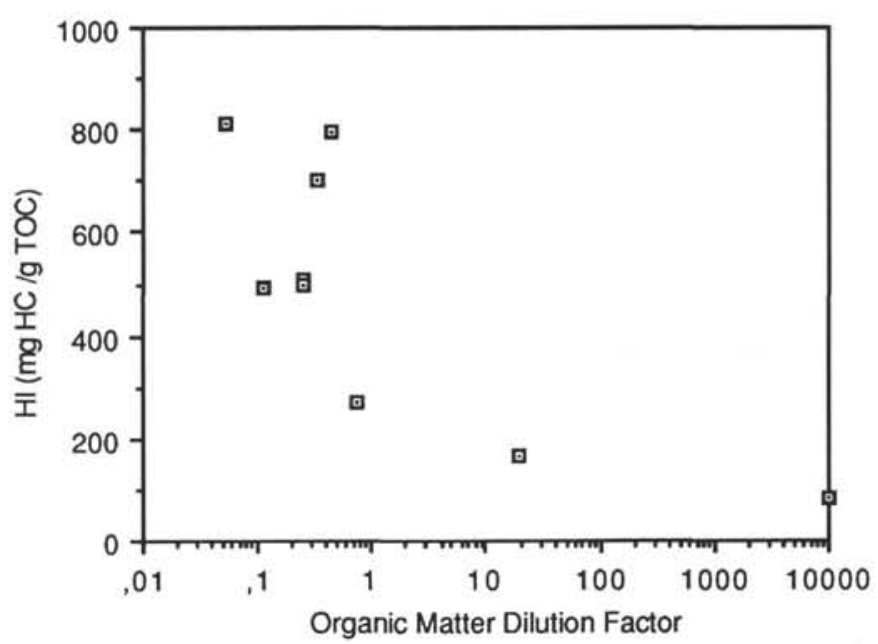

Figure 8. Organic matter dilution factor (terrestrial/ marine organic matter) $v s$ hydrogen index (HI) obtained by Rock-Eval pyrolysis (mg $\mathrm{HC} / \mathrm{g} \mathrm{TOC}$ ). The ratio, defined as lignaceous organic matter (LOM) vs. amorphous organic matter (AOM) + other structured elements (OSE), has been calculated using qualitative data obtained on isolated organic matter preparations.

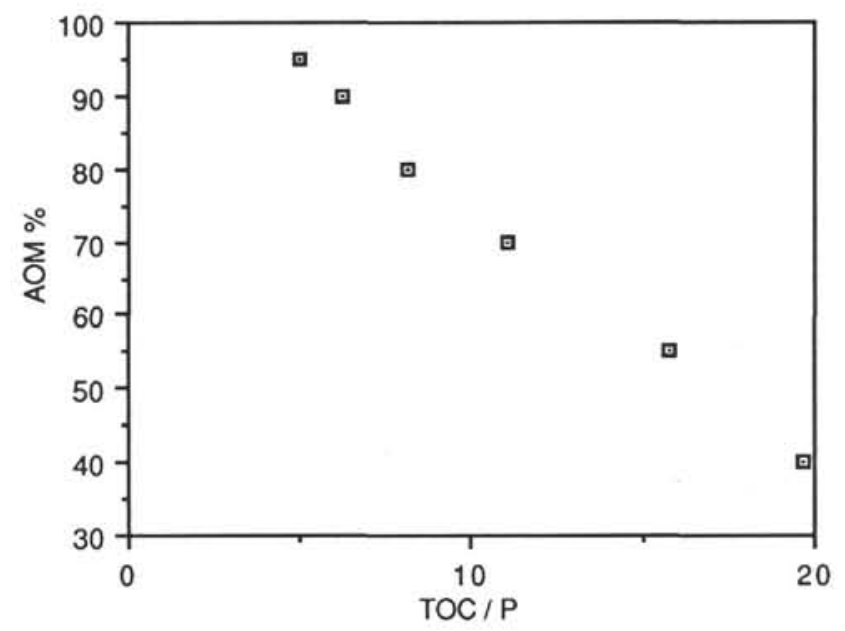

Figure 9. Amount of marine amorphous organic matter (AOM) in isolated organic matter vs. TOC/P weight ratio 1 in the sediment, for the first $200 \mathrm{~m}$. The AOM percentage derives from qualitative data of isolated organic matter preparations.

and the hydrogen index (HI) (Fig. 8); high $\mathrm{HI}$ values being characteristic of dominantly marine organic matter.

The relationship between the type of the organic matter and the geochemical composition of the bulk sediment is also displayed in Figure 9, where the sediment TOC/P ratio is plotted against the amount of amorphous organic matter. A low TOC/P ratio could represent a higher contribution of marine organic matter through both a high phosphorous content and decrease of terrestrial carbon. The terrestrial organic input is known to deplete the bulk organic matter in phosphorus (Ingall and Van Kappelen, 1990). At present, we have no results concerning the precipitation of phosphorousbearing minerals in sediments, and we need further investigations to use TOC/P as an indicator of organic degradation or dilution.

We also considered the structured vs. amorphous marine organic matter ratio (OSE/AOM). This ratio takes into ac- 


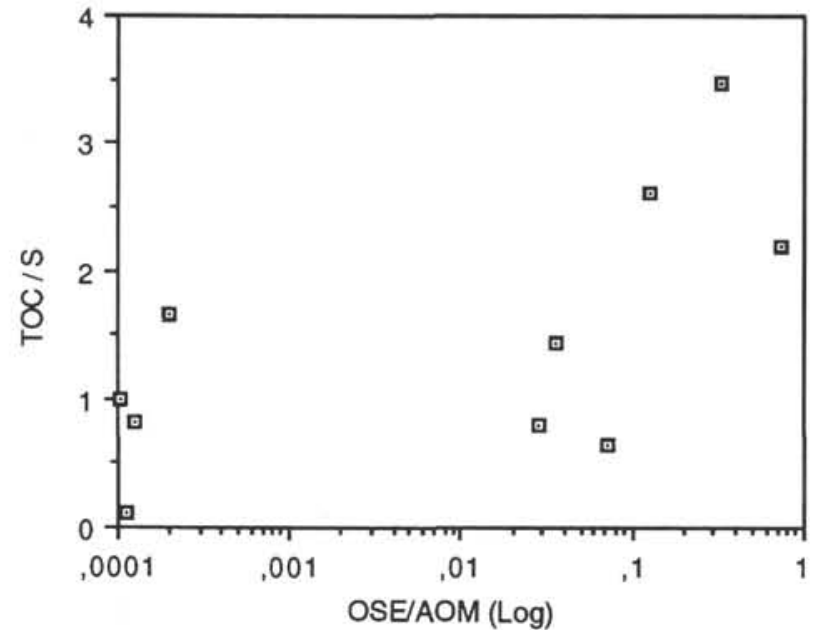

Figure 10. Marine organic matter OSE/AOM ratio vs. TOC/S. The ratio, defined as structured/amorphous organic matter, is calculated from qualitative data obtained on isolated organic matter preparations.

count the evolution of the marine biomass in which some constituents (OSE) are more resistant than others (AOM). We observe that higher values are associated with high TOC/S and conversely (Fig. 10). The AOM origin could be partly associated to the sulfate reduction process and the inferred pyritization process.

This assumption is also based on petrographic observations, which show that this phenomenon is accompanied by an increase of framboidal pyrite in the amorphous organic matter. According to Goldhaber and Kaplan (1975) and Westrich and Berner (1984), the AOM represents that part of marine organic components remaining after the decomposition of the most easily metabolizable compounds through anaerobic bacterial activity. However, we did not find any relationship between the preservation factor and the hydro-

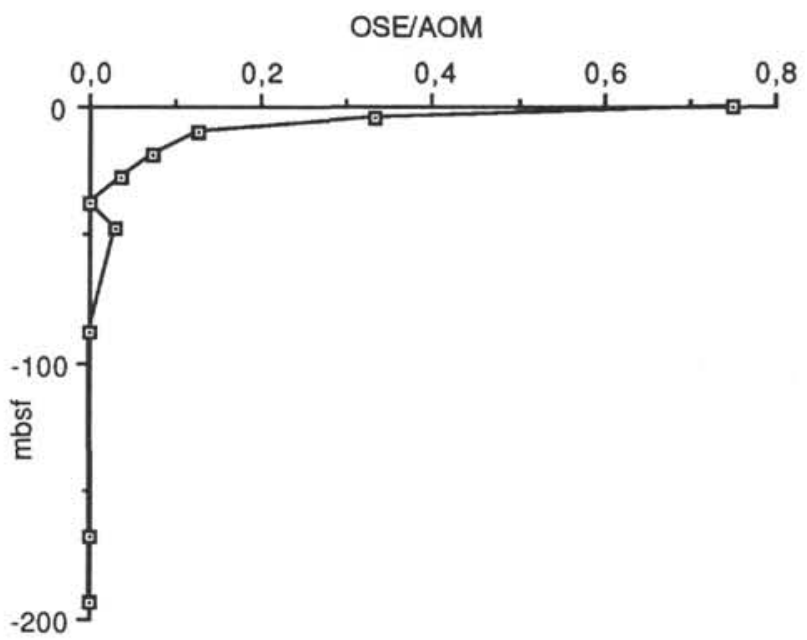

Figure 11. Distribution with depth, (for the first $200 \mathrm{~m}$ of the hole) of the marine organic matter OSE/AOM ratio. The ratio, defined as structured/amorphous organic matter, is calculated from qualitative data obtained on isolated organic matter preparations.

gen index, probably because of the dilution by continental components.

In the first lithostratigraphic unit (Unit I), the OSE/AOM ratio decreases with depth in the core. Below this unit, dilution varies in a similar manner (Fig. 12); a low dilution by continental components is accompanied by low structured/ amorphous marine organic matter ratios.

\section{CONCLUSIONS}

Due to the sediment accumulation rates of Celebes Basin sediments (4-8 cm/k.y.), autochthonous marine deposits have buried metabolizable organic matter, as was revealed by the degradation processes recorded in the pore waters.

Sulfate reduction effects were investigated through the study of pyritization and the composition of organic matter.

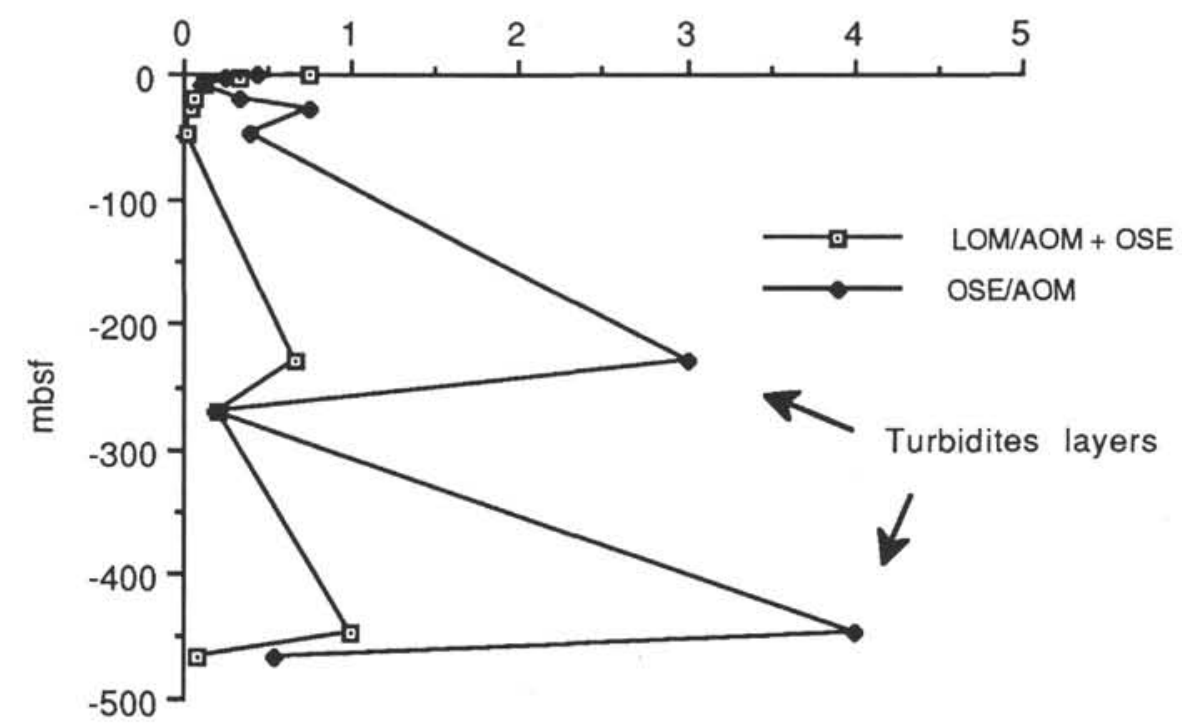

Figure 12. Comparison of distributions with depth (for the organic facies Unit A) of the marine organic matter OSE/AOM ratio and the organic matter dilution factor. These factors present strong variations down the Hole, essentially due to lithostratigraphic changes. Turbidite layers are characterized by a high dilution of total organic matter by terrestrial components. These two factors do not seem to depend on the upper part of the column. 
Petrographic observations of organic matter show the interactive influences of dilution and preservation processes, on the characters of the fossilized organic matter. We found a positive relationship between the genetic type of the organic matter and the sulfate reducing activity that indicates a greater availability of metabolizable components for sulfate reduction in organic matter of marine origin.

However, we also found evidence for a relationship between the composition of marine organic matter and the sulfate reducing effect. The main effect of these processes would be the "morphological" degradation (AOM) of marine organic particles (i.e., phytoplankton?). In the Celebes Basin sediments, the dilution of total organic carbon by continental organic matter is too high to evaluate the chemical change of the marine organic matter by itself.

Deeper layers rich in terrestrial matter (turbidites from organic Units A and B) are typical of detrital dilution that differently affects the total organic matter. The high sediment accumulation rate of the turbidites partly hinders the degradation of marine organic matter by oxic or suboxic processes at the water-sediment interface. Furthermore, this continental organic matter, still reactive at the time of deposition, has been further degraded by sulfate- reducing processes. In any case, the available metabolizable organic matter and the inferred sulfate reduction is greater in the turbidites.

This study also shows that some widely used trend as the decrease of the TOC/S ratio with depth, which is generally considered as indicative of early diagenesis, may be affected by variations of organic matter dilution. The supply of terrestrial organic debris influences the fossilization of organic matter in two ways: first by the addition of organic carbon to the autochthonous organic supply, and second by its contribution to the bulk available organic matter for the sulfate reduction, depending on whether or not it was degraded before deposition.

\section{ACKNOWLEDGMENTS}

We thank the Ocean Drilling Program for providing samples from Leg 124. This study was partly supported by the ODP program and CNRS (France). Special thanks go to F. Champion for preparing the samples and to J. Simonato for technical assistance in SEM studies.

\section{REFERENCES}

Berner, R. A., 1974. Kinetics models for the early diagenesis of Nitrogen, Sulfur, Phosphorus and Silicon in anoxic marine sediments. In Goldberg E. D. (Ed.), The Sea, Vol. 5: New York (J. Wiley \& Sons), 5:427-450.

Berner, R. A., and Raiswell, R., 1983. Burial of organic carbon and pyrite sulfur in sediments over Phanerozoic time: a new theory. Geochim. et Cosmochim. Acta, 47:855-852.

Berner, R. A., and Raiswell, R., 1984. C/S method for distinguishing freshwater from marine sedimentary rocks. Geology, 27:41-65.

Bertrand, P., Lallier-Vergès, E., and Grall, H., 1991. Organic petrology of Neogene sediments from north Indian Ocean (Ocean Drilling Program, Leg 117): Amount, type and preservation of organic matter. Proc. ODP, Sci. Results, 117: College Station, TX (Ocean Drilling Program), 587-594.
Chukhrov, F., Gorshkov, A., Yermilova, L., Berezovskaya, V., and Sivtsov, V., 1982. Mineral forms of manganese and iron in oceanic sediments. Tranl. 1981. Int. Geol. Rev., 24:465-480.

Davis, H. R., Byers C. W., and Dean W. E., 1988. Pyrite formation in the lower cretaceous Mowry Shales: effect of organic matter type and reactive iron content. Am. J. Sci., 288:873-890.

Degens, E. T., 1965. Geochemistry of Sediments. Englewood Cliffs, N. J. (Prentice Hall).

Espitalié, J., Madec, M., and Tissot, B., 1977. Source rock characterization method for petroleum exploration. Proc. Annu. Offshore Technol. Conf., 9:399-404.

Galimov E. M., $1980 .{ }^{13} \mathrm{C} /{ }^{12} \mathrm{C}$ in kerogen. In Durand, B., (Ed.)., Kerogen: Paris (Editions Technip), 271-298.

Goldhaber, M. B., and Kaplan, I. R., 1975. Controls and consequences of sulfate reduction rates in recent marine sediments. Soil Sci., 119:42-55.

Henrichs, S. M., and Reeburgh, W. S., 1987. Anaerobic mineralization of marine sediment organic matter: Rates and the role of anaerobic processes in the oceanic carbon economy. Geomicrobiology, J., 5:191-237.

Ingall, E. D., and Van Kappelen, P., 1990. Relation between sedimentation rate and burial of organic phosphorus and organic carbon in marine sediments. Geochim. et Cosmochim. Acta, $54: 373-386$.

Jorgensen, B. B., 1982. Mineralization of organic matter in the sea bed-the role of sulphate reduction. Nature, 296:643-645.

Manheim, F. T., and Sayles, F. L., 1974. Composition and origin of interstitial waters of marine sediments based on deep sea drill cores. In E. D. Goldberg (Ed.), The Sea (Vol. 5): New York (J. Wiley \& Sons), 527-568.

Rangin, C., Silver, E., von Breymann, M., et al., 1990. Proc. ODP, Init. Repts., 124: College Station, TX (Ocean Drilling Program).

Raynaud, J. F., Lugardon, B., and Lacrampe-Couloume, G., 1988. Observation de membranes fossiles dans la matière organique "amorphe" de roches mères de pétrole. C. R. Acad. Sci. Paris, Ser. 307:1703-1709.

Sayles, F. L., and Manheim, F. T., 1975. Interstitial solutions and diagenesis in deeply buried marine sediments: results from the D.S.D.P. Geochim. et Cosmochim. Acta, 39:103-127.

Schoell, M., 1984. Wasserstoff-und Kohlenstoffisotope in organischen Substanzen, Erdoelen und Erdgasen. Geologches Jahrb., Reihe D, Heft 67.

Schroeder R. A., 1975. Absence of -alanine and aminobutyric acid in fleaned foraminiferal shells: implications for use as a chemical criterion to indicate removal of non-indigenous amino acid contaminants. Earth Planet. Sci. Lett., 25:274-278.

Sorokin, Y. I., 1962. Experimental investigation of bacterial sulfate reduction in Black Sea sediments using ${ }^{35} \mathrm{~S}$. Mikrobiologiya,3: $402-410$.

Toth, D. J., and Lerman, A., 1977. Organic matter reactivity and sedimentation rates in the ocean. Am. J. Sci., 277:465-485.

Waples, D. W., and Sloan, J. R., 1980. Carbon and Nitrogen diagenesis in deep-sea sediments. Geochim. et Cosmochim. Acta, 44: 1463-1470.

Westrich, J. T., and Berner, R. A., 1984. The role of sedimentary organic matter in bacterial sulfate reduction: The $\mathrm{G}$ model tested. Limnol. Oceanogr., 29:236-249.

Date of initial receipt: 2 July 1990

Date of acceptance: 1 March 1991

Ms 124B-179 

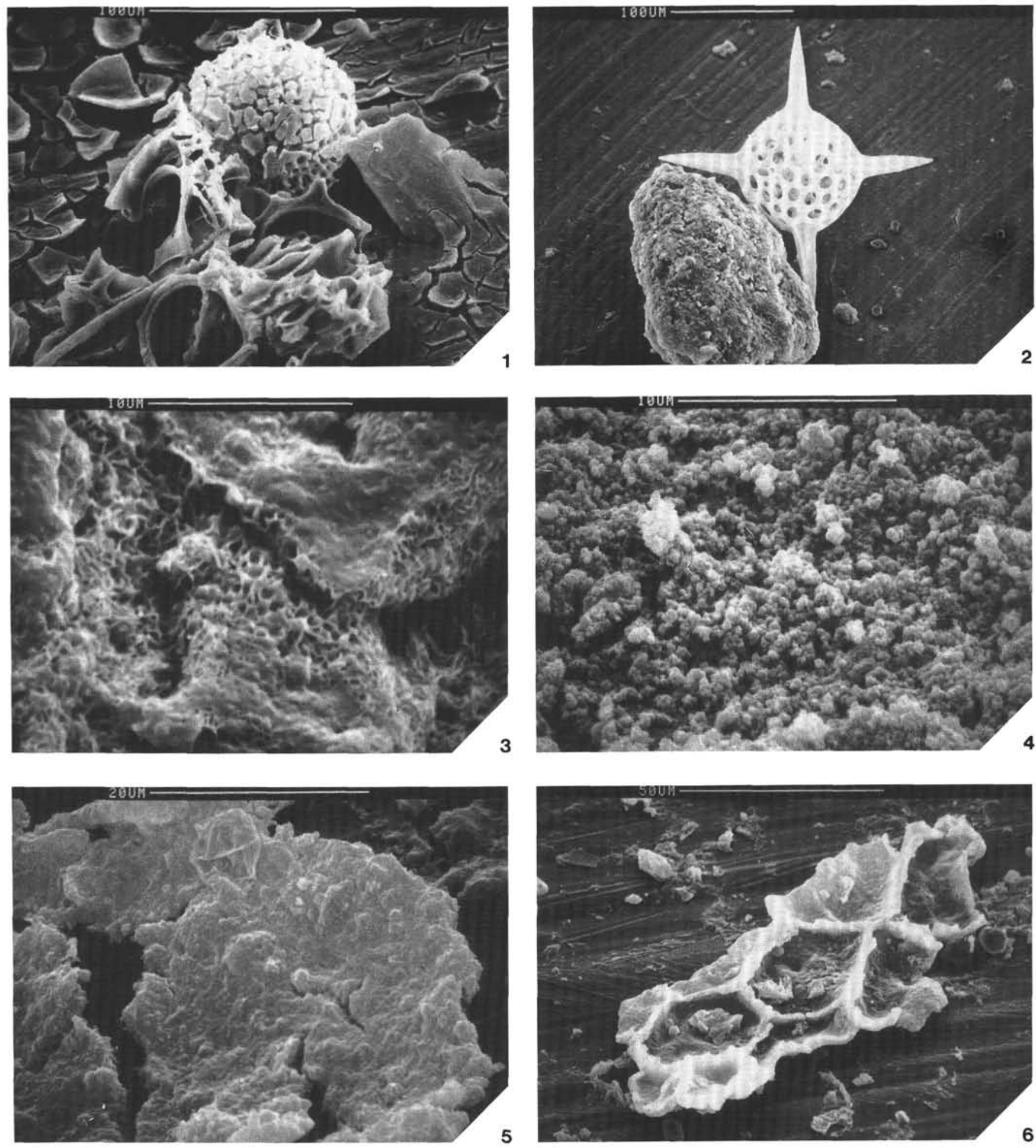

Plate 1. SEM observations. 1. Radiolarian, silicoflagellate, and volcanic glass covered with an organic matter coating; Sample 124-767A-1H-1, 23-28 cm, coarse fraction 80-125 $\mu \mathrm{m}$. 2. Radiolarian and pellet; Sample 124-767B-5H-1, 10-15 cm, coarse fraction $125 \mu \mathrm{m}$. 3. Detail from the fine material present in the fraction $<20 \mu \mathrm{m}$ from Sample 124-767A-1H-1, 23-28 cm. Qualitative EDS spectrum indicates the occurrence of Si, $\mathrm{Al}$, and $\mathrm{K}$, its textural aspect is that of organic matter. 4. Detail of the amorphous organic matter as seen on photograph 5; Sample 124-767 A-1H-1, $23-28 \mathrm{~cm}$. 5. Amorphous organic matter with associated dinoflagellate (upper part) and pollen (lower part); Sample 124-767B-5H-1, 10-15 cm. 6. Cuticle; Sample 124-767B-25X-4, 76-78 cm. 

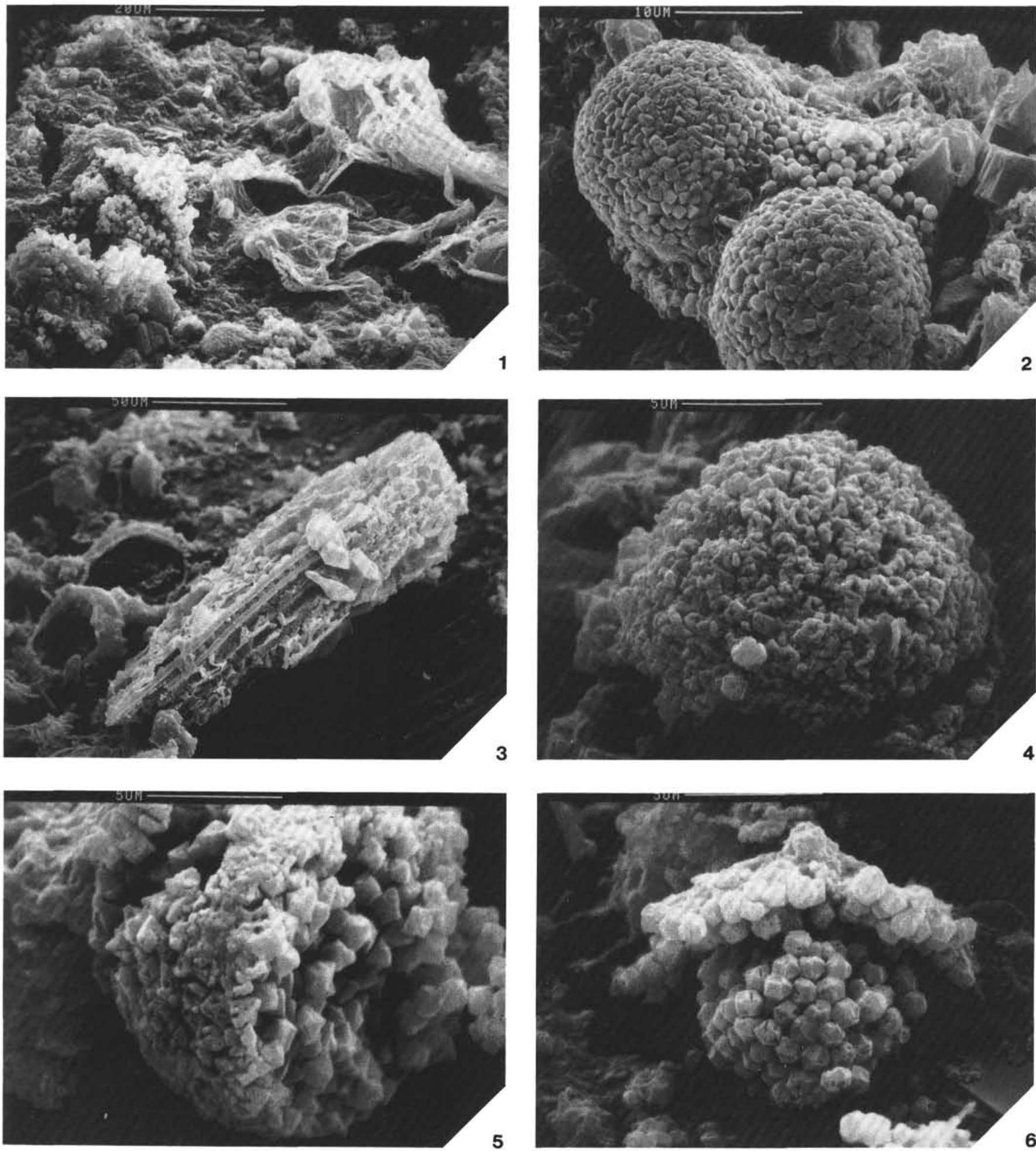

Plate 2. SEM observations. 1. Amorphous organic matter associated with algae (upper part) and pyrite framboid (left part); Sample 124-767B-2H-1, 43-48 cm. 2. Pyrite framboids as observed in clayey aggregates of sieved sediments; Sample 124-767B-40X-3, 134-136 cm. 3. Degraded lignaceous debris; Sample 124-767A-1H-1, 23-28 cm. 4. Pyrite framboid composed of poorly organized crystals, Sample 124-767B$5 \mathrm{H}-1,10-15 \mathrm{~cm}$. 5. Poorly and well-organized pyrite crystals in a lone framboid; Sample 124-767B-5H-1, 10-15 cm. 6. Well-organized pyrite framboid; Sample 124-767B-5H-1, 10-15 cm. 